Ambiente \& Água - An Interdisciplinary Journal of Applied Science
ISSN 1980-993X - doi:10.4136/1980-993X
www.ambi-agua.net
E-mail: ambi.agua@gmail.com

\title{
An Artemia franciscana bioassay for the monitoring of lipophilic phycotoxins in marine bivalve mollusc cultures: An alternative to screening testing?
}

\author{
ARTICLES doi:10.4136/ambi-agua.2549
}

Received: 27 Mar. 2020; Accepted: 19 Aug. 2020

\author{
Alailton dos Reis Guaralde1 ${ }^{1 D}$; Daniela Almeida de Souza1 ${ }^{1 D}$; \\ Celso Luiz Possas Guimarães Júnior ${ }^{2}{ }^{D}$; Rafael Soares Guimarães ${ }^{2}{ }^{\oplus}$; \\ Victor Barbosa Saraiva ${ }^{3}$; José Augusto Ferreira da Silva ${ }^{4}$; \\ Marcos Massao Murata ${ }^{5}$; Renato Matos Lopes $^{6}$ iD; \\ Rachel Ann Hauser-Davis ${ }^{7}$; Manildo Marcião de Oliveira $^{3 *}$
}
${ }^{1}$ Programa de Pós Graduação em Engenharia Ambiental (PPEA). Laboratório de Ecotoxicologia e Microbiologia Ambiental (LEMAM). Instituto Federal de Educação, Ciência e Tecnologia Fluminense (IFFluminense), Estrada Cabo Frio-Búzios, s/n, CEP: 28909-971, Cabo Frio, RJ, Brazil.
E-mail: alailtonreis@yahoo.com.br,danielabio@hotmail.com
${ }^{2}$ Departamento de Biologia. Instituto Federal de Educação, Ciência e Tecnologia Fluminense (IFFluminense), Estrada dos Búzios, s/n, CEP: 28293-660, Cabo Frio, RJ, Brazil.
E-mail: cj_celso@hotmail.com, luigis2guima@gmail.com
${ }^{3}$ Laboratório de Ecotoxicologia e Microbiologia Ambiental (LEMAM). Instituto Federal de Educação, Ciência e Tecnologia Fluminense (IFFluminense), Estrada Cabo Frio-Búzios, s/n, CEP: 28909-971, Cabo Frio, RJ, Brazil. E-mail: vsaraiva@iff.edu.br
${ }^{4}$ Programa de Pós Graduação em Engenharia Ambiental (PPEA). Instituto Federal de Educação, Ciência e Tecnologia Fluminense (IFFluminense), Rodovia Amaral Peixoto, Km 164, CEP: 27932-050, Macaé, RJ, Brazil. E-mail: jaferreirasilva@gmail.com
${ }^{5}$ Departamento de Biofísica e Biometria. Instituto de Biologia Roberto Alcantara Gomes (IBRAG). Universidade
Estadual do Rio de Janeiro (UERJ), Avenida Boulevard 28 de setembro, ${ }^{\circ} 87$ (fundos), CEP: 20551-030,
Rio de Janeiro, RJ, Brazil. E-mail: muratauerj@gmail.com
${ }^{6}$ Laboratório de Comunicação Celular. Instituto Oswaldo Cruz. Fundação Oswaldo Cruz (Fiocruz), Avenida Brasil, n 4.365, CEP: 21040-360, Manguinhos, RJ, Brazil. E-mail: rmatoslopes@gmail.com
${ }^{7}$ Instituto Oswaldo Cruz. Laboratório de Avaliação e Promoção da Saúde Ambiental. Fundação Oswaldo Cruz (Fiocruz), Avenida Brasil, n 4.365, CEP: 21040-360, Manguinhos, RJ, Brazil.
E-mail: rachel.hauser.davis@gmail.com
*Corresponding author. E-mail: manildodpicf@gmail.com

\begin{abstract}
In Brazil, malacoculture is developed mainly in the state of Santa Catarina, followed by São Paulo and Rio de Janeiro. In the course of the development of Brazilian mariculture, legislation has addressed the sanitary requirements necessary for bivalve commercialization. However, monitoring phycotoxins is a challenge, due to often costly reference methods. In this context, this study evaluated the use of alternative ecotoxicological and bioanalytical methods using Artemia franciscana (brine shrimp) lethality assessments. The results confirm that, although correlations between the reference mouse assay and the brine shrimp assays were not high, the alternative brine shrimp assay may be incorporated into phycotoxin monitoring programs, as hepatopancreas methanolic extracts of mussel (Perna perna) containing DSP resulted in high lethality rates. Therefore, further methodological adjustment studies and the inclusion of other enzymatic and toxicological models are required to further assess these
\end{abstract}


Alailton dos Reis Guaralde et al.

differences, and associations between ecotoxicological methods as early-alarm methods are encouraged.

Keywords: Arraial do Cabo, harmful algae, Perna perna.

\section{Bioensaios com Artemia franciscana para monitoramento de ficotoxinas lipofílicas em cultivo de moluscos bivalves marinhos: Uma alternativa para teste de alarme?}

\section{RESUMO}

No Brasil, a malacocultura é desenvolvida principalmente no estado de Santa Catarina, seguida por São Paulo e Rio de Janeiro. No curso do desenvolvimento das atividades da maricultura brasileira, a legislação se adaptou aos requisitos sanitários necessários à comercialização de bivalves. No entanto, o monitoramento de ficotoxinas é um desafio, devido a métodos de referência frequentemente caros. Nesse contexto, o objetivo deste estudo foi avaliar o uso de métodos ecotoxicológicos e bioanalíticos alternativos usando a Artemia franciscana (artemia). Os resultados confirmam que, embora as correlações entre o ensaio de referência em camundongos e os ensaios com artemia não sejam altas, o ensaio alternativo com artemia pode ser incorporado aos programas de monitoramento de ficotoxinas, pois os extratos metanólicos do hepatopâncreas de mexilhões (Perna perna) contendo DSP resultaram em altas taxas de letalidade. Portanto, estudos adicionais de ajustes metodológicos e a inclusão de outros modelos enzimáticos e toxicológicos são necessários para avaliar essas diferenças, e são encorajadas associações entre métodos ecotoxicológicos como métodos de alarme precoce.

Palavras-chave: algas nocivas, Arraial do Cabo, Perna perna.

\section{INTRODUCTION}

Bivalve mollusc cultivation has increased in the last decades, and currently obtains high yields (FAO, 2016). However, the possibility of contamination by toxins produced by certain microalgae species (phycotoxins) is an obstacle to shellfish production and consumption and may lead to product embargos when harmful algal blooms (HAB) occur in cultivation areas (Simões, 2011). HAB comprise excessive proliferation of certain phytoplankton species in short periods of time, due to favorable development conditions (Castro and Moser, 2012). As bivalve molluscs are filter feeders, many toxins can be ingested and stored in their tissues, bioaccumulating and potentially biomagnifying throughout the trophic chain (Barbosa et al., 2019), causing poisoning in several organisms, including humans, through the consumption of contaminated mollusks (Barbieri, 2009; Proença et al., 2011). In marine coastal environments, most phycotoxins are produced by dinoflagellates (Castro and Moser, 2012; Hallegraeff, 2003).

In Brazil, Interministerial Normative Instruction 07/2012 of the Ministries of Agriculture, Livestock and Supply (MAPA) and the former Ministry of Fisheries and Aquaculture (MPA) indicate which microalgae species are capable of producing toxins and list their main symptoms. The nomenclature of each intoxication is related to the main symptom caused in humans. For example, Diarrheic Shellfish Poisoning (DSP) indicates a diarrheal syndrome which produces abdominal discomfort, nausea, vomiting and diarrhea (Grattan et al., 2016), caused by okadaic acid (AO) and derivatives such as the dinophysistoxin group (DTXs), yessotoxins (YTXs) and pectonotoxins (PTXs) (Castro and Moser, 2012; Barbieri, 2009; Hallegraeff, 2003). Okadaic acid (OA) and DTX toxins are lipophilic substances that can contaminate shellfish meat (Uchida et al., 2018) produced by planktonic dinoflagellates (Castro and Moser, 2012; Hallegraeff, 2003). 
Other issues may also result from the ingestion of toxins produced by these organisms, such as tumors and mutagenic and immunotoxic effects (Kolrep et al., 2016). Specifically, cyanobacterial microcystin-LR (MC-LR), OA and DTX may also lead to inhibition of PP1 and PP2A phosphatases proteins MC-LR and OA are the most widely distributed hepatotoxins worldwide (Wu et al., 2015). Several analytical methodologies for the analysis of lipophilic phycotoxins have been applied. In this context, mass spectrometry liquid chromatography (LCMS/MS) has been set as the reference method of the EU since 2011 (EC No. 15/2011) (Suzuki et al., 2009; Garibo et al., 2012), while mouse bioassays (Yasumoto et al., 1978) are considered an alternative method in this regard (Visciano et al., 2016). A number of other alternative or complementary techniques are, however, permitted by EC Regulation No. 15/2011, either performed individually or in combination, provided they fulfill the proper role of official methods of providing protection to public health (Garibo et al., 2012). These include immunoassays and other chromatography techniques, including high performance liquid chromatography (HPLC), thin layer chromatography (TLC), gas chromatography-mass spectrometry (GC-MS) and gas chromatography-infrared spectroscopy (GC-IV) (Fujii et al., 2004). However, these methodologies have some drawbacks, i.e., they are very expensive, require specialized labor (in the case of liquid and gas chromatographies) and use methodologies that are not ethically adequate (mouse testing). Enzymatic assays, on the other hand, are less expensive than chromatographic techniques and can be applied to detect various pollutants, such as pesticides and metals (Ochoa et al., 2013, Chouteau et al., 2005), as well as their effects. In this regard, phosphatase inhibition assays have also been proposed to detect lipophilic phycotoxin effects (Garibo et al., 2012).

Ecotoxicological assays are routinely applied in monitoring polluted environments (Anselmo et al., 2011) as well as in assessing bioactive substances and phytotoxins. Assays using species belonging to the Artemia genus are a staple in many countries (Astuya et al., 2015; Chang and Gall, 2013), and have been suggested as an early ecotoxicological alarm test for evaluating the effects of palytoxin and palytoxin-related compounds produced by benthic dinoflagellates (Faimali et al., 2012).

In this regard, this study sought to verify the associated use of alternative phosphatase inhibition tests and an artemia nauplii lethality bioassay for the detection of DSP toxins as a viable alternative to monitor phytotoxin contamination in cultivated mussels.

\section{MATERIAL AND METHODS}

\subsection{Study area}

The town of Arraial do Cabo is located in the coastal zone of the state of Rio de Janeiro, $158 \mathrm{~km}$ distant from the capital, between coordinates $22^{\circ} 57^{\prime} 57^{\prime \prime} \mathrm{S}, 42^{\circ} 1^{\prime} 40^{\prime}$ ' W. It includes approximately $152,305 \mathrm{~km}^{2}$, with a population of about 27,700 (IBGE, 2020) (Figure 1).

\subsection{Bivalve mollusc sampling and processing}

Perna perna mussels (50 individuals per sampling) were collected between August 2013 and May 2014, always in the morning. Mean shell length was $8.5 \pm 0.59 \mathrm{~cm}$ and mean weight of $48.61 \pm 8.45 \mathrm{~g}$. After transportation to the laboratory, individual hepatopancreas were removed, pooled until reaching 20 to $25 \mathrm{~g}$, and stored at $-20^{\circ} \mathrm{C}$.

\subsection{Methanolic hepatopancreas extract preparation}

After drying the pooled hepatopancreas samples in an oven at constant temperature of $60^{\circ} \mathrm{C}$ for 24 hours, methanolic hepatopancreas extracts were prepared by mixing $100 \mathrm{~mL}$ methanol to $20 \mathrm{~g}$ of the dehydrated hepatopancreas samples with the aid of surgical scissors and a porcelain mortar and pestle. After homogenization and $30 \mathrm{~min}$ of rest, the supernatants were filtered (Milex ${ }^{\mathrm{TM}}, 45 \mu \mathrm{m}$, Millipore) and the same volume of methanol was added for a second 
extraction step for a further $30 \mathrm{~min}$. The two supernatants were then joined in order and were submitted to a rotary evaporation step at $60^{\circ} \mathrm{C}$ until complete evaporation.

Subsequently, the concentrated extracts were resuspended in $5 \mathrm{~mL}$ of deionized water and left to stand for $30 \mathrm{~min}$. After this period, $1 \mathrm{~mL}$ of the solutions were applied to a solid phase C18 reverse phase chromatography column containing DIAION HP 20 (Sigma Aldrich, São Paulo). The mobile phase elution step was performed by successively applying different methanol concentrations. The obtained solutions were then dried by rotary evaporation and the $100 \%$ methanol fraction was stored at $-20^{\circ} \mathrm{C}$ for subsequent toxicological and enzymatic assays.

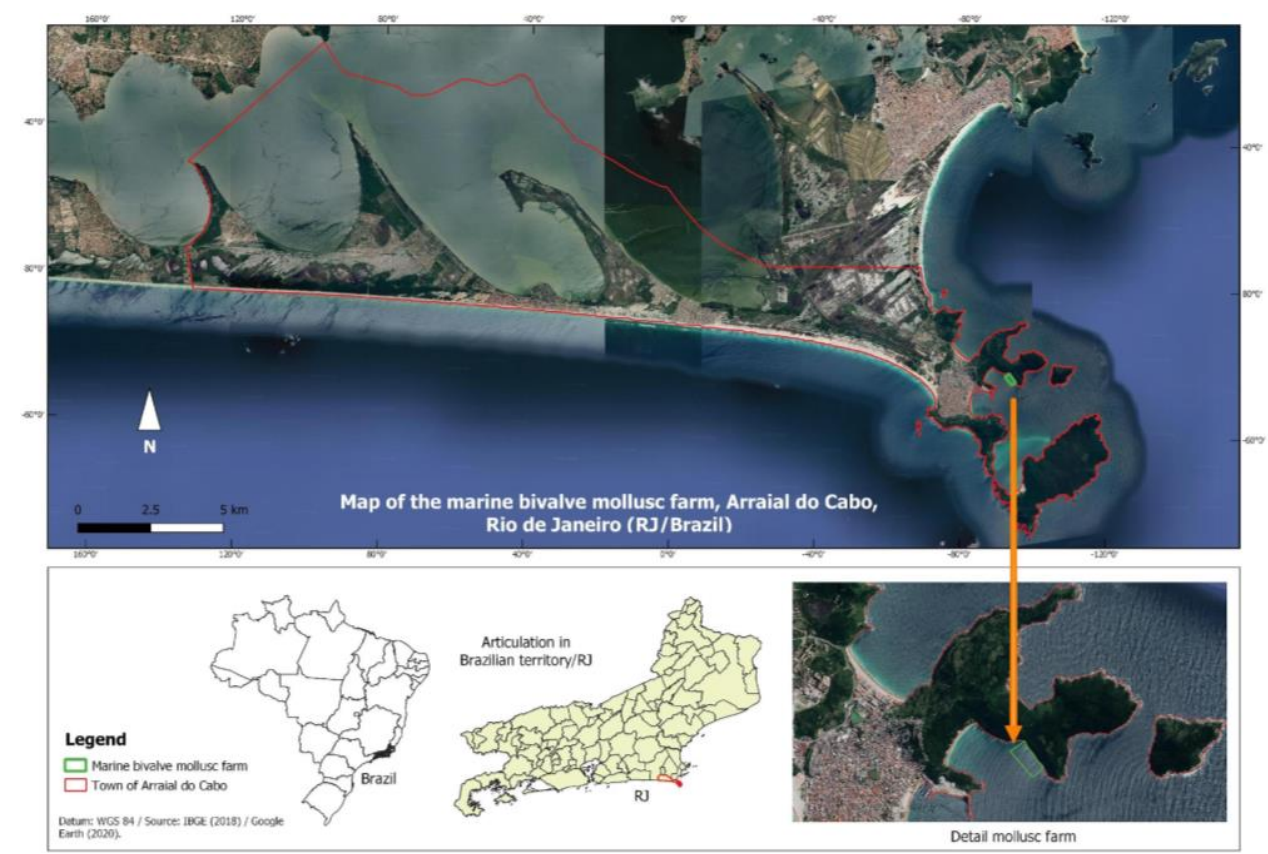

Figure 1. Map of the marine bivalve mollusc farm, Arraial do Cabo, Rio de Janeiro.

\subsection{Microcystis aeruginosa extract preparation}

Freeze-dried Microcystis aeruginosa containing the microcystin-LR toxin was used as a positive phycotoxin control for the artemia assays, cultivated from a NPLJ-4 (Laughinghouse et al., 2012) strain kindly provided from the IBCCF Ecophysiology and Cyanobacterial Toxicology Laboratory, belonging to the Federal University of Rio de Janeiro (UFRJ), and the Toxicological Biochemistry Laboratory, belonging to the State University of Rio de Janeiro (UERJ). Preparation of the M. aeruginosa extract followed the same methodology previously described for mussel hepatopancreas, with modifications in the methanol ratio, set at $2.5 \mathrm{~mL}$ methanol to $50 \mathrm{mg}$ of lyophilized M. aeruginosa cells (NPLJ-4), followed by three methanol extractions and a centrifugation step to obtain the supernatant, instead of filtering.

\subsection{Artemia franciscana ecotoxicological assays}

Artemia cysts were obtained from a commercial pet shop (Maramar Pet, Arraial do $\mathrm{Cabo} / \mathrm{RJ})$. Cysts were decapsulated using calcium hypochlorite and hatched in artificial seawater $\left(2 \mathrm{~g} . \mathrm{L}^{-1} \mathrm{NaHCO}_{3}+8 \mathrm{~g} . \mathrm{L}^{-1} \mathrm{NaCl}\right)$ at room temperature $\left(25^{\circ} \mathrm{C}\right)$ for $24 \mathrm{~h}$, under constant aeration and lighting $\left(250 \mu \mathrm{mol} \cdot \mathrm{m}^{-2} \cdot \mathrm{s}^{-1}\right)$.

Artemia franciscana ecotoxicological assays were performed according to Meyer et al. (1982), with modifications. All assays were carried out in 6-well cell culture plates, with each well containing 10 brine shrimp nauplii. The positive control consisted of a Microcystis aeruginosa strain containing the microcystin-LR toxin, while the negative control consisted of $5 \mathrm{~mL}$ of artificial seawater. The positive control and hepatopancreas extracts were resuspended 
in $1 \mathrm{~mL}$ of artificial seawater solution containing $0.01 \%$ ethanol, used to improve extract. Each well received $1 \mathrm{~mL}$ of the extract solution to be tested and $4 \mathrm{~mL}$ of artificial seawater, totaling $5 \mathrm{~mL}$. All assays were conducted in triplicate. The nauplii were exposed to the extract for 24 h. Lethality was considered when no nauplii movements were observed for at least 10 s under observation with a binocular microscope. Results are presented as nauplii mortality percentages.

\subsection{Phosphatase enzyme sample preparation and determinations}

Artemia franciscana enzymatic extracts were prepared by weighing $1 \mathrm{~g}$ of brine shrimp (recently hatched nauplii at the II-III stage) and homogenizing this mass at a 1:4 ratio in a Tris/ $\mathrm{HCl} 50 \mathrm{mmol} \mathrm{L}^{-1} \mathrm{pH} 7.4$ containing sucrose $250 \mathrm{mM}$, EDTA 5 mmol.L ${ }^{-1}$, DTT 1 mmol.L1, PMSF $0.1 \mathrm{mmol} . \mathrm{L}^{-1}$. After thirty passes in a Potter-Elvehjem tissue homogenizer (Potter, 1955), the homogenates were centrifuged at $10,000 \mathrm{~g}$ for $60 \mathrm{~min}$ at $4^{\circ} \mathrm{C}$ and the obtained supernatants were used as a source of phosphatase enzymes.

Total phosphatase (TF) activity was determined according to Rivasseau et al. (1999) and Bouaïcha et al. (2002) with modifications. Briefly, the assay buffer (40 mM Tris/HCl, pH 8.4, containing $34 \mathrm{mmol} . \mathrm{L}^{-1} \mathrm{MgCl}_{2}, 4 \mathrm{mmol} . \mathrm{L}^{-1}$ EDTA and 4 nmol.L ${ }^{-1}$ DDT) was mixed with pnitrophenyl phosphate as substrate at a final concentration $9.8 \mathrm{mmol} . \mathrm{L}^{-1}$ and $100 \mu \mathrm{L}$ of the Artemia franciscana enzyme fraction, totaling a final volume of $200 \mu \mathrm{L}$. Product formation was measured by continuous absorption at $405 \mathrm{~nm}$ on a microplate reader for 6 min and enzyme activity calculations were performed using the p-nitrophenol absorption coefficient $\left(16,890 \mathrm{M}^{-1} \cdot \mathrm{cm}^{-1}\right)$. Data were expressed as one enzyme unit (U) $\mu$ mol.min ${ }^{-1}$ p-nitrophenol per milliliter. For the inhibition test, Artemia franciscana enzyme fractions and methanolic mussel hepatopancreas extracts incubated for 1 hour at $20^{\circ} \mathrm{C}$ were used. All assays were performed in triplicate and results are presented as enzyme inhibition percentages, to facilitate interpretation and comparison to other studies.

\subsection{Statistical analyses}

Data were analyzed using the Graph Pad Prism v. 6.0 and Microsoft Excel v. 2003 software packages. A simple linear regression was observed in order to verify potential correlations (Pearson's correlation test) between the proposed brine shrimp assay and the phosphatase inhibition assay. The results are presented as means and standard deviations (means \pm SD) of triplicates and the $t$ student's test $(p<0.05)$ was applied between control samples and the extracts.

\section{RESULTS AND DISCUSSION}

DSP phycotoxins are lipophilic substances that can contaminate shellfish meat (Uchida $e t$ $a l ., 2018)$ and are produced by planktonic dinoflagellates belonging to the Dinophysis (D. acuta, D. acuminata, D. caudata, D. fortii, D. miles, D. norvegica, D. sacculus and D. tripos) and Phalacroma genera ( $P$. mitra and $P$. rotundatum); as well as benthic species belonging to the Prorocentrum genus ( $P$. lima, $P$. arenarium, $P$. belizeanum, $P$. concavum, $P$. faustiae, $P$. hoffmannianum, P. mild and P. maculosum) (Castro and Moser, 2012; Hallegraeff, 2003). In this regard, Souza et al. (2016) analyzed the same hepatopancreas mussel samples collected in January and May 2014 assessed herein using the mouse bioassay and reported the presence of Dinophysis acuminata (120). The current study assessed the same samples used by Souza et al. (2016) for the brine shrimp and phosphatase inhibition assays.

Artemia sensitivity to the positive control corroborates previous assessments carried out using another Artemia species, Artemia salina, exposed to cyanobacteria extracts, where an LC50 of below $50 \mu \mathrm{g} \mathrm{mL}^{-1}$ was reported (Falch et al., 1995). In another study, Batista et al. (2013) evaluated Artemia salina sensitivity to extracts obtained from two Microcystis sp. strains (NPLJ-4 and TAC 95) and reported high sensitivity to these cyanotoxins (LC50 24h of 5.7 
mg.L $\mathrm{L}^{-1}$ and $3.7 \mathrm{mg} . \mathrm{L}^{-1}$, respectively for NPLJ-4 and TAC 95). However, when compared to other organisms (Daphnia magna, LC50 24h $2 \mathrm{mg} . \mathrm{L}^{-1}$ and $0.8 \mathrm{mg} . \mathrm{L}^{-1}$ and Ceriodaphnia dubia, CL5024h $1.2 \mathrm{mg} . \mathrm{L}^{-1}$ and $0.6 \mathrm{mg} . \mathrm{L}^{-1}$ for MPLJ-4 strains and TAC 95, respectively) Artemia salina was more resistant, and, thus, deemed the most adequate species to assess the relationship between microcystins present in cyanobacterial strain extracts.

\subsection{Artemia franciscana lethality assay}

High A. franciscana mortality rates of over $50 \%$ for all assessed months were observed after 24 hours of exposure to the methanolic extracts. In August 2013 and May 2014, the mortality rates of the metanolic extract was comparable to the effects of the pure microcystinLR positive control, of $90 \%$ or more (Figure 2).

The dinoflagellate Dinophysis acuminate was detected in seawater (120 and 7040 Cell.L ${ }^{-1}$ ) and in Perna perna hepatopancreas samples collected in January and May 2014 by Souza et al. (2016), indicating the presence of a lipophilic toxin causing DSP in the reference mouse bioassay, which may have been responsible for the high toxicity of around $90 \%$ observed for these mussel extracts. No correlations were detected between high nauplii mortality and mouse bioassay toxicity for the other assessed months.

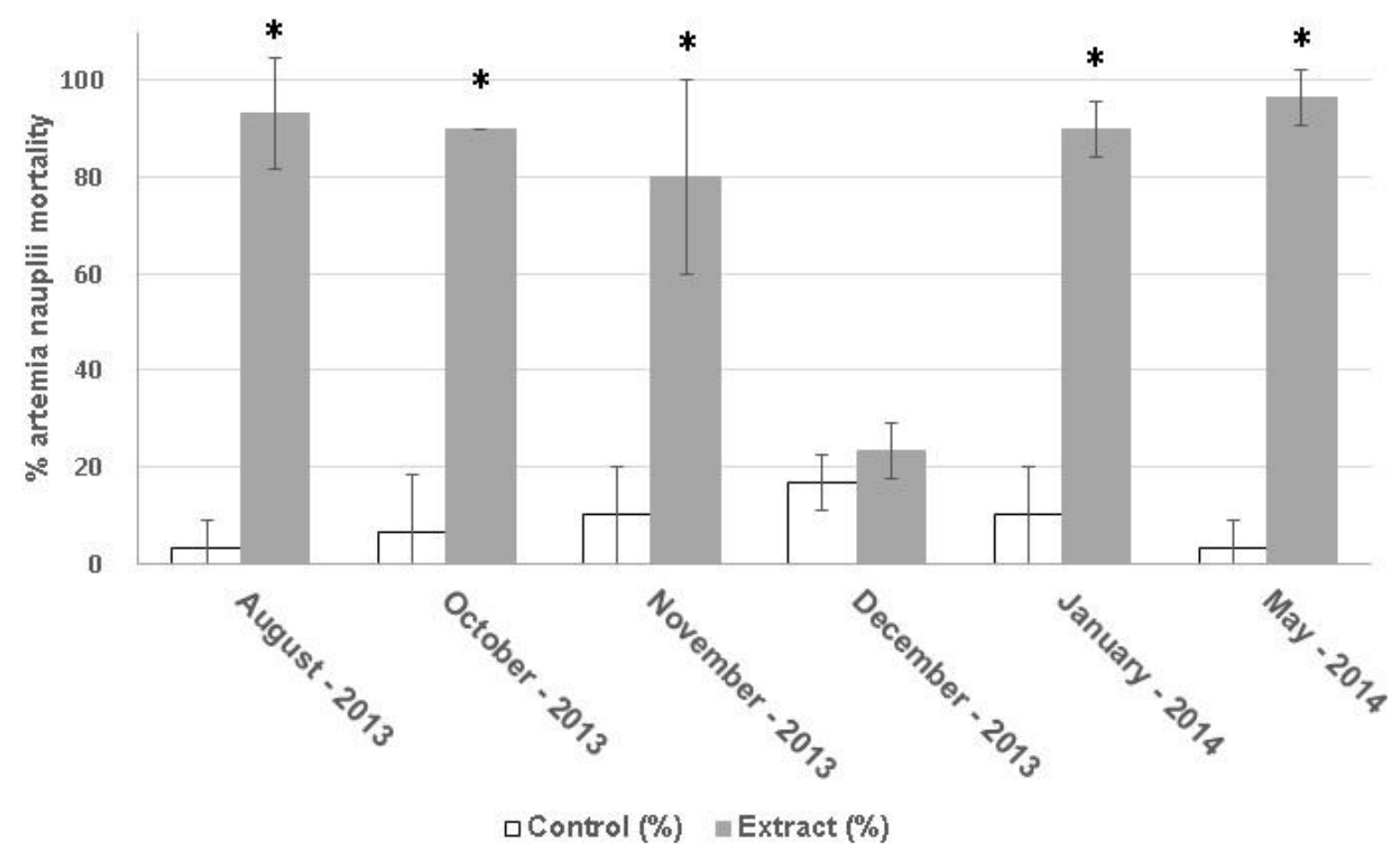

Figure 2. Mortality percentages (mean $\pm \mathrm{SD}, \mathrm{n}=3$ ) of Artemia franciscana nauplii exposed to methanolic mussel hepatopancreas extracts. (*) Indicates significant difference between the means extract vs control (Student's $t$ test, $\mathrm{p}<0.05$ ).

Several brine shrimp assays have been applied to assess the toxicity of several dinoflagellates and diatoms in the literature. For example, these shrimp assays have been reported as adequate for the assessment of the toxicity of the dinoflagellate species Amphidinium carterae, Coolia monotis and Ostreopsis ovata in a study conducted in the Northern Ionian Sea (Mediterranean Sea), applied comparatively and alongside phytotoxin evaluations concerning the larval development of sea urchin (Paracentrotus lividus) and hemolysis tests on human erythrocytes (Pagliara and Caroppo, 2012). Comparative toxicity studies of the effects of different Ostreopsis ovata concentrations on artemia nauplii and fish larvae have also been reported, and the results indicate that artemia nauplii are an adequate test 
organism due to their high sensitivity (Faimali et al., 2012).

Artemia nauplii assessments expressed as cyst hatching success have also been deemed efficient in toxicity evaluations regarding Skeletonema costatum and Nitzschia commutata diatoms and short-chain aldehydes (Caldwell et al., 2003). However, low acute toxicity was observed when artemia nauplii were exposed to Pseudochattonella and Chattonella marina strains, which are ichthyotoxic (Skjelbred et al., 2011).

\subsection{Phosphatase Enzyme Assay}

The phosphatase enzyme assay has been routinely used for the detection of cyanobacterial microcystins and okadaic acid produced by certain dinoflagellate species (Triantis et al., 2010; Eberhart et al., 2013), and no differences have been reported when comparing this method with reference methods, such as mouse bioassays and fluorometric detection high performance liquid chromatography (HPLC-FLD) using 1-bromoacetylpyrene (BAP) as the pre-column derivative reagent (Prassopoulou et al., 2009).

Only exposure to extracts obtained from samples collected in January resulted in phosphatase enzyme inhibition of about or over $50 \%$, while the other samples displayed lower than $40 \%$ inhibition rates (Figure 3).

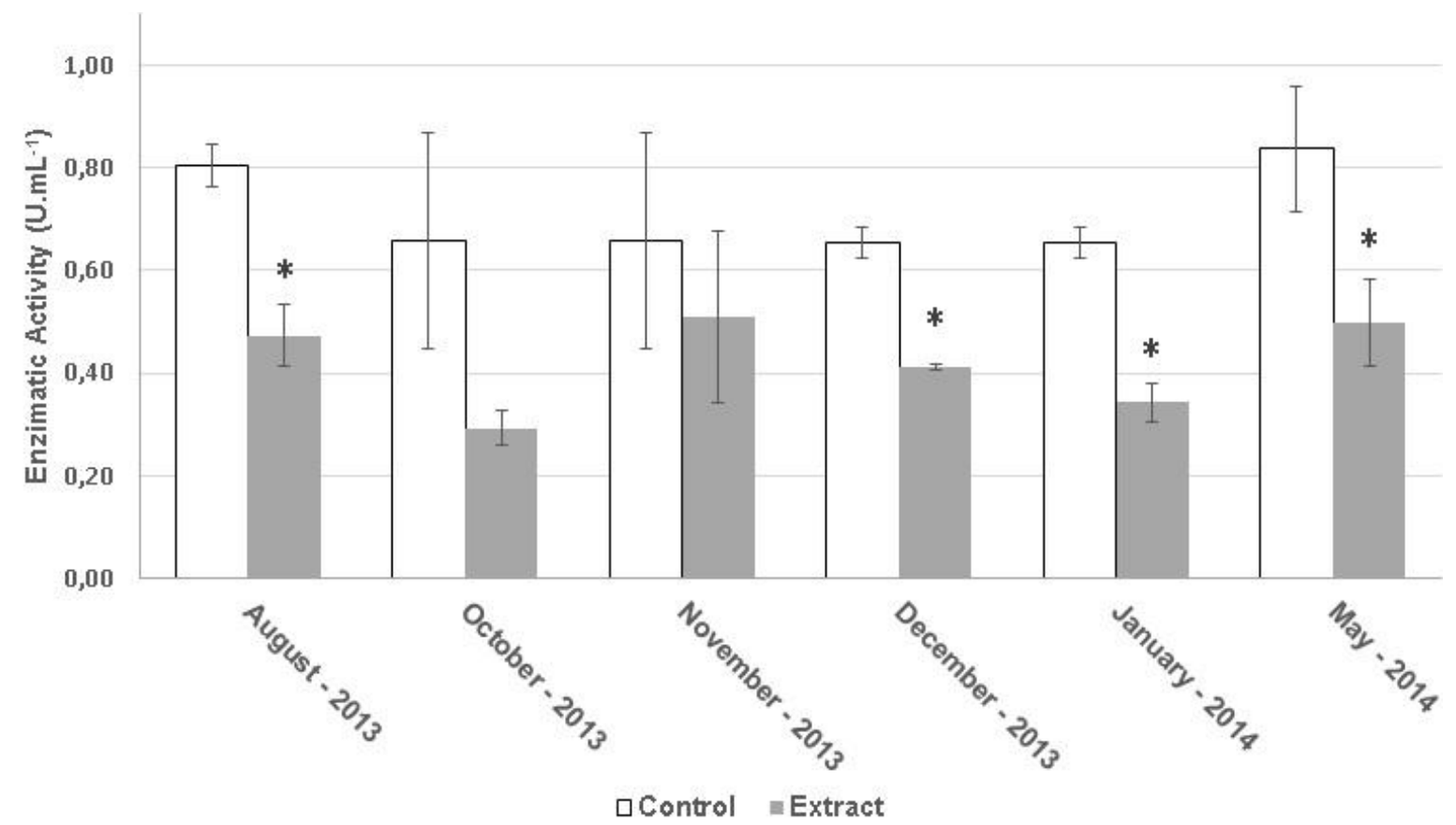

Figure 3. Enzymatic phosphatase activity (mean $\pm \mathrm{SD}, \mathrm{n}=3)$ ) in Artemia franciscana submitted to methanolic mussel hepatopancreas extracts. $(*)$ Indicates significant difference between the means extract vs control (Student's t test, $\mathrm{p}<0.05$ ).

The inhibition pattern of around $50 \%$ is similar to that reported in another study for genetically engineered phosphatases $2 \mathrm{~A}$ and purified red blood cell enzymes in samples that had accumulated lipophilic toxins, carried out by Garibo et al. (2012) when analyzing mussels and oysters collected in Catalonia and Galicia.

\subsection{Correlations between the brine shrimp lethality assay and phosphatase inhibition assay}

No correlation between phosphatase inhibition and artemia mortality was observed (Figure 4). It is probable that acute DSP toxin toxicity (okadaic acid and derivatives) may not only related to phosphatase inhibition (Munday, 2013), and that other mechanisms of action may play a role in toxicity and artemia nauplii mortality (Rossini and Hess, 2010). This has 
been reported previously in other assessments, where derivatives such as DTX-4 and 7-Odocosahexaenoyl-OA, for example, display high acute mouse toxicity and low protein phosphatase 1 and 2A inhibition (Munday, 2013).

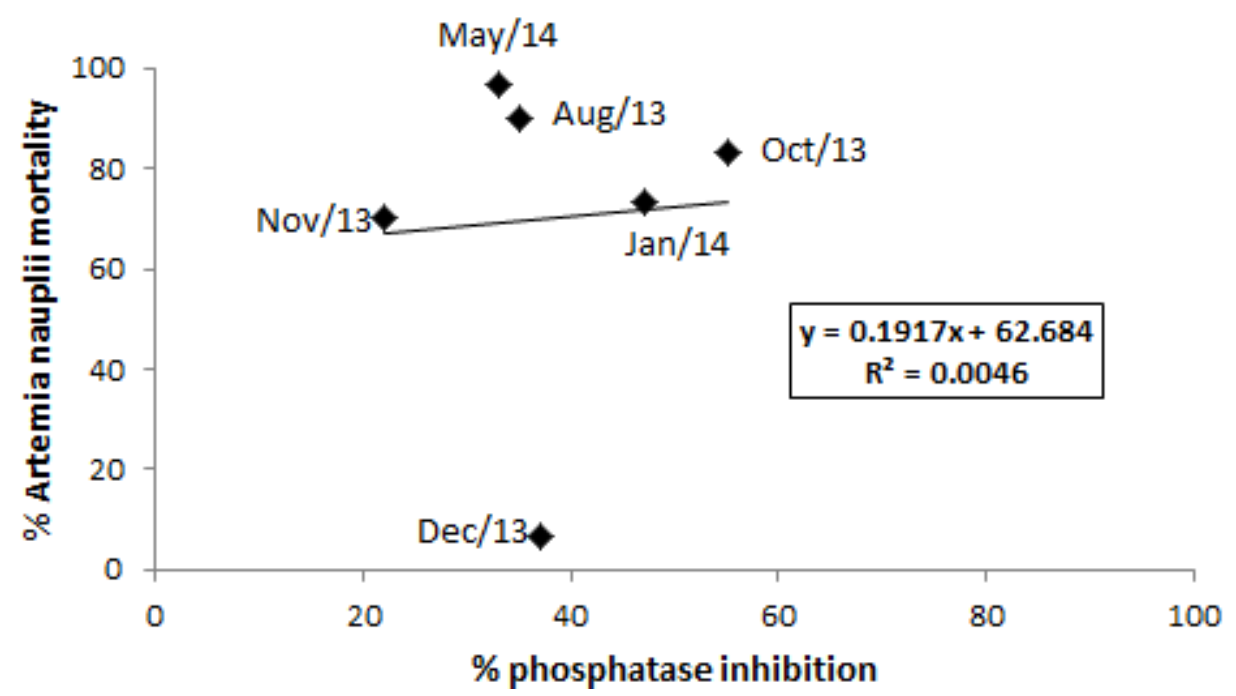

Figure 4. Correlations between artemia nauplii phosphatase activity inhibition and lethality when exposed to methanolic extracts. No correlation (Pearson's correlation coefficient $\mathrm{p}<0.05)$ was observed between the assessed variables.

\subsection{Correspondence with bioassays from another study}

The dinoflagellate Dinophysis acuminata was detected in the January and May 2014 hepatopancreas samples by Souza et al. (2016), which may have been the cause for the high mortality Artemia franciscana rates observed herein for these months. The phosphatase inhibition was significant for these sampling points.

Souza et al. (2016), using the same samples as assessed herein, carried out the DSP bioassay which assessed mouse deaths. The mouse deaths observed for the January and May samples also coincide with high mortality rates and phosphatase inhibition in the Artemia franciscana trial carried out herein, corroborating the dinoflagellate Dinophysis acuminata as the toxic agent responsible for these deaths.

A simple comparison of the brine shrimp bioassay and phosphatase assays carried out herein with the results reported by Souza et al. (2016) for the same samples concerning Perna perna microalgae content and mouse bioassay results is displayed in Table 1. In the present study, both Artemia franciscana nauplii and phosphatase enzyme displayed sensitivity to the Microcystis aeruginosa standard used as the positive control in the assays (Table 1).

Table 1. Comparison of brine shrimp bioassay and phosphatase assays results with Perna perna hepatopancreas microalgae content and mouse bioassay assessments.

\begin{tabular}{ccccc}
\hline Sampling date & $\begin{array}{c}\text { Percentage brine } \\
\text { shrimp lethality } \\
\text { (CV\%) }\end{array}$ & $\begin{array}{c}\text { Percentage } \\
\text { phosphatase inhibition } \\
(\mathrm{CV} \%)\end{array}$ & $\begin{array}{c}\text { Detected microorganism } \\
\text { (cells.L-1) } \\
\text { (Souza } \text { et al., 2016) }\end{array}$ & $\begin{array}{c}\text { Mouse DSP assay } \\
\text { (Souza } \text { et al., 2016) }\end{array}$ \\
\hline Positive control & $93(6)$ & $72(8)$ & M. aeruginosa (NPLJ-4) & - \\
Jan-14 & $74(6)$ & $48(11)$ & Dinophysis acuminata $(120)$ & Positive \\
May-14 & $96(6)$ & $42(17)$ & Dinophysis acuminata $(7040)$ & Positive \\
\hline
\end{tabular}

(CV\%) Coefficient of variation. 
A $100 \%$ agreement between fluorometric detection high performance liquid chromatography (HPLC-FLD), using 9-athryldiazomethane (ADAM) as the precolumn derivative reagent, with mass spectrometry-coupled liquid chromatography method in tandem (LC-MS / MS), applied for detection of okadaic acid has been previously reported, as well as a $97.1 \%$ agreement observed between each of these methods with the reference mouse bioassay (Louppis et al., 2010). Although a high agreement was not noted herein between brine shrimp lethality assay, the phosphatase inhibition assay and the reference mouse assay, the first two display the potential to be applied as alarm methods to aid decision-making in malaculture activities prior to further, more costly, methods using mice, as the same the January and May samples containing Dinophysis acuminata led to both high Artemia franciscana mortality rates and mice deaths in the DSP assay carried out by Souza et al. (2016).

In this regard, other enzymatic and toxicological models are required to further assess these differences, identifying the minimum inhibitory DSP concentrations and validation parameters, such as selectivity, limits of detection and quantification, accuracy, precision, linearity, sensitivity, robustness and reproducibility for each of the evaluated factors should be taken into account.

\section{CONCLUSIONS}

The present study indicates that the early-alarm method of brine shrimp assay may be incorporated into phytotoxin monitoring programs in marine-farmed bivalve molluscs. Artemia nauplii efficiently demonstrated lethality and phosphatase inhibition due to exposure to hepatopancreas methanolic extracts containing DSP, corroborated by mouse deaths caused by exposure to the same samples.

Contrasting results for the brine shrimp phosphatase inhibition assay and lethality assays may be due to different toxicodynamic pathways in place between brine shrimp and mice, probably occurring not only through phosphatase inhibition. Because of this, further methodological adjustments studies and the inclusion of other enzymatic and toxicological models are required to further assess these differences, and associations between methods for application as early-alarm methods are encouraged.

\section{REFERENCES}

ANSELMO, H. M. R.; KOERTING, L.; DEVITO, S.; VAN DEN BERG, J. H.J.; DUBBELDAM, M.; KWADIJK, C.; MURK, A. J. Early life developmental effects of marine persistent organic pollutants on the sea urchin Psammechinus miliaris. Ecotoxicology and Environmental Safety, v. 74, n. 8, p. 2182-2192, 2011. https://doi.org/10.1016/j.ecoenv.2011.07.037

ASTUYA, A.; RAMÍREZ, A. E.; ABALlAY, A.; ARAYA, J.; SILVA, J.; ULlOA, V.; FUENTEALBA, J. Neurotoxin-like compounds from the ichthyotoxic red tide alga Heterosigma akashiwo induce a TTX-like synaptic silencing in mammalian neurons. Harmful Algae, v. 47, p.1-8, 2015. https://doi.org/10.1016/j.hal.2015.04.006

BARBIERI, E. O Perigo das Biotoxinas Marinhas. São Paulo: Instituto de Pesca, 2009.

BARBOSA, V.; SANTOS, M.; ANAClETO, P.; MAUlVAUlT, A. L.; POUSÃOFERREIRA, P.; COSTA, P. R.; MARQUES, A. Paralytic Shellfish Toxins and Ocean Warming: Bioaccumulation and Ecotoxicological Responses in Juvenile Gilthead

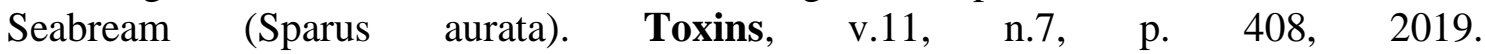
https://doi.org/10.3390/toxins11070408 
BATISTA, A. D.; SUZUKI, L. Y.; KURODA, E. K. 2013. Avaliação da toxicidade de extratos de cepas de cianobactérias com diferentes organismos-teste. Fórum Ambiental da Alta Paulista, v. 9, n. 11, p. 186-201, 2013. http://dx.doi.org/10.17271/198008279112013671

BOUAÏCHA, N.; MAATOUK, I.; VINCENT, G.; LEVI, Y. A colorimetric e fluorimetric microplate assay for the detection of microcystin LR in drinking water without preconcentration. Food and Chemical Toxicology, v. 40, p. 1677-1683, 2002. https://doi.org/10.1016/S0278-6915(02)00103-5

CALDWELL, G. S.; BENTLEY, M. G.; OLIVE, P. J. W. The use of a brine shrimp (Artemia salina) bioassay to assess the toxicity of diatom extracts and short chain aldehydes. Toxicon, v. 42, n. 3, p. 301-306, 2003. https://doi.org/10.1016/S0041-0101(03)00147-8

CASTRO, N. O.; MOSER, G. A. O. Florações de algas nocivas e seus efeitos ambientais. Oecologia Australis, v. 16, n. 2, p. 235-264, 2012.

CHANG, F. H.; GALL, M. Pigment compositions and toxic effects of three harmful Karenia species, Karenia concordia, Karenia brevisulcata and Karenia mikimotoi (Gymnodiniales, Dinophyceae), on rotifers and brine shrimps. Harmful Algae, v. 27, p. 113-120, 2013. https://doi.org/10.1016/j.hal.2013.05.005

CHOUTEAU, C.; DZYADEVYCH, S.; DURRIEU, C.; CHOVELON, J-M. A bi-enzymatic whole cell conductometric biosensor for heavy metal ions and pesticides detection in water samples. Biosensors and Bioelectronics, v. 21, n. 2, p. 273-281, 2005. https://doi.org/10.1016/j.bios.2004.09.032

EBERHART, B. T. L.; MOORE, L. K.; HARRINGTON, N.; ADAMS, N. G.; BORCHERT, J.; TRAINER, V. L. Screening Tests for the Rapid Detection of Diarrhetic Shellfish Toxins in Washington State. Marine Drugs, v. 11, n. 10, p. 3718 -3734, 2013. https://doi.org/10.3390/md11103718

FAIMALI, M.; GIUSSANI, V.; PIAZZA, V.; GARAVENTA, F.; CORRÀ, C.; ASNAGHI, V.; PRIVITERA, D.; GALLUS, L.; CATTANEO-VIETTI, R.; MANGIALAJO, L.; CHIANTORE, M. Toxic effects of harmful benthic dinoflagellate Ostreopsis ovata on invertebrate and vertebrate marine organisms. Marine Environmental Research, n. 76, p. 97-107, 2012. https://doi.org/10.1016/j.marenvres.2011.09.010

FALCH, B. S.; KÖNIG, G. M.; WRIGHT, A. D.; STICHER, O.; ANGERHOFER, C. K.; PEZZUTO, J. M.; BACHMANN, H. Biological activities of cyanobacteria: evaluation of extracts and pure compounds. Planta Medica, n. 61, p. 321-328, 1995. https://dx.doi.org/10.1055/s-2006-958092

FAO. The state of world fisheries and aquaculture. Rome, 2016.

FUJII, I.; YASUOKA, Y.; CHANG, Y. C.; KWON-CHUNG, K.; EBIZUKA, Y. Hydrolytic polyketide shortening by ayg $1 \mathrm{p}$, a novel enzyme involved in fungal melanin biosynthesis. The Journal of Biological Chemistry, v. 279, p. 44613-44620, 2004. https://dx.doi.org/10.1074/jbc.M40675820

GARIBO, D.; DÀMASO, E.; EIXARCH, H., IGLESIA, P.; FERNÁNDEZ-TEJEDOR, M.; DIOGĖNE, J.; PAZOS, Y.; CAMPÀS, M. Protein phosphatase inhibition assays for okadaic acid detection in shellfish: Matrix effects, applicability and comparison with LCMS/MS analysis. Harmful Algae, v. 19, p. 68-75, 2012. https://doi.org/10.1016/j.hal.2012.06.001 
GRATTAN, L. M.; HOLOBAUGH, S.; MORRIS JR, J. G. Harmful algal blooms and public health. Harmful algae, v. 57, p. 2-8, 2016. https://doi.org/10.1016/j.hal.2016.05.003

HALLEGRAEFF, G. M. Harmful algal blooms: a global overview. In: ALLEGRAEFF, G. M.; ANDERSON, D. M.; CEMBELlA A. D. (eds.). Manual on Harmful Marine Microalgae. Paris: UNESCO, 2003.

IBGE. Arraial do Cabo. 2020. Available at: https://cidades.ibge.gov.br/brasil/rj/arraial-docabo/panorama Access: 15 Jan. 2020.

KOLREP, F.; HESSEL, S.; THESE, A.; EHLERS, A.; REIN, K.; LAMPEN, A. Differences in metabolism of the marine biotoxin okadaic acid by human and rat cytochrome P450 monooxygenases. Archives of toxicology, v. 90, n. 8, p. 2025-2036, 2016. https://doi.org/10.1007/s00204-015-1591-9

LAUGHINGHOUSE IV, H. D.; PRÁ, D.; SILVA-STENICO, M. E.; RIEGER, A.; FRESCURA, V. D. S.; FIORE, M. F.; TEDESCO, S. B. Biomonitoring genotoxicity and cytotoxicity of Microcystis aeruginosa (Chroococcales, cyanobacteria) using the Allium cepa test. Science of the Total Environmental, v. 432, p. 180-188, 2012. https://doi.org/10.1016/j.scitotenv.2012.05.093

LOUPPIS, A. P.; BADEKA, A. V.; KATIKOU, P.; PALEOLOGOS, E. K.; KONTOMINAS, M. G. Determination of okadaic acid, dinophysistoxin-1 and related esters in Greek mussels using HPLC with fluorometric detection, LC-MS/MS and mouse bioassay. Toxicon, v. 55, n. 4, p. 724-33, 2010. https://doi.org/10.1016/j.toxicon.2009.10.026

MEYER, B. N.; FERRIGNI, N. R.; PUTNAM, J. E.; JACOBSEN, L. B.; NICHOLS, D. E.; MACLAUGHLIN, J. L. Brine shrimp: a convenient general bioassay for active plant constituents. Planta Medica, v. 45, p. 31-34, 1982. https://doi.org/10.1055/s-2007971236

MUNDAY, R. Is protein phosphatase inhibition responsible for the toxic effects of okadaic acid in animals? Toxins, v. 5, n. 2, p. 267-285, 2013. https://doi.org/10.3390/toxins5020267

OCHOA, V.; RIVA, C.; FARIA, M.; BARATA, C. Responses of B-esterase enzymes in oysters (Crassostrea gigas) transplanted to pesticide contaminated bays form the Ebro Delta (NE, Spain). Marine Pollution Bulletin, v. 66, n. 1-2, 15, p. 135-142, 2013. https://doi.org/10.1016/j.marpolbul.2012.09.032

PAGLIARA, P.; CAROPPO, C. Toxicity assessment of Amphidinium carterae, Coolia cfr. monotis and Ostreopsis cfr. ovata (Dinophyta) isolated from the northern Ionian Sea (Mediterranean Sea). Toxicon, v. 60, n. 6, p. 1203-1214, 2012. https://doi.org/10.1016/j.toxicon.2012.08.005

PRASSOPOULOU, E.; KATIKOU, P.; GOERGANTELIS, D.; KYRITSAKIS, A. Detection of okadaic acid and related esters in mussels during diarrhetic shellfish poisoning (DSP) episodes in Greece using the mouse bioassay, the PP2A inhibition assay and HPLC with fluorimetric detection. Toxicon v. 53, n.2, p. 214-227, 2009. https://doi.org/10.1016/j.toxicon.2008.11.003

PROENÇA, L. A. O.; FONSECA, R. S.; PINTO, T. O. Microalgas em área de cultivo do litoral de Santa Catarina. São Carlos: RiMa, 2011. 90 p. 
RIVASSEAU, C.; RACAUD, P.; DEGUIN, A.; HENNION, M.C. Development of a bioanalytical phosphatase inhibition test for the monitoring of microcystins in environmental water samples. Analytica Chimica Acta, v. 394, p. 243-257, 1999. https://doi.org/10.1016/S0003-2670(99)00301-3

ROSSINI, G. P.; HESS, P. Phycotoxins: chemistry, mechanisms of action and shellfish poisoning. In: Molecular, clinical and environmental toxicology. Birkhäuser Basel, v. 100, p. 65-122, 2010. https://doi.org/10.1007/978-3-7643-8338-1_3

SIMÕES, E. Impacto da floração da alga Nociva Dinophisis acuminata sobre o sistema imune de ostras Crassostrea gigas e mexilhões Perna perna cultivados em Santa Catarina. 2011. 84f. Dissertação (Mestrado em Aquicultura) - Centro de Ciências Agrárias, Universidade Federal de Santa Catarina, Florianópolis, 2011.

SKJELBRED, B.; HORSBERG, T. E.; TOLLEFSEN, K. E.; ANDERSEN, T.; EDVARDSEN, B. Toxicity of the ichthyotoxic marine flagellate Pseudochattonella (Dictyochophyceae, Heterokonta) assessed by six bioassays. Harmful Algae, v. 10, n. 2, p. 144-154, 2011. https://doi.org/10.1016/j.hal.2010.08.007

SOUZA, D. A.; OLIVEIRA, M. M.; NEVES, M. H. B. N.; SCHRAMM, M. A.; PROENÇA, L.; SARAIVA, V. B. Occurrence of DSP toxins in Perna perna mussels (Linnaeus, 1758) and toxic marine phytoplankton in Arraial do Cabo, RJ / Brazil. In: INTERNATIONAL CONFERENCE ON HARMFUL ALGAE - ICHA, 17., 2016. Florianópolis. Proceedings[...] Florianópolis: ICHA, 2016.

SUZUKI, T.; MIYAZONO, A.; BABA, K.; SUGAWARA, R.; KAMIYAMA, T. LC-MS/MS analysis of okadaic acid analogues and other lipophilic toxins in single-cell isolates of several Dinophysis species collected in Hokkaido, japan. Harmful Algae, v. 8, n. 2, p. 233-238, 2009. https://doi.org/10.1016/j.hal.2008.06.001

TRIANTIS, T.; TSIMELI, K.; KALOUDIS, T.; THANASSOULIAS, N.; LYTRAS, E.; HISKIA, A. Development of an integrated laboratory system for the monitoring of cyanotoxins in surface and drinking waters. Toxicon, v. 55, n. 5, p. 979-989, 2010. https://doi.org/10.1016/j.toxicon.2009.07.012

UCHIDA, H.; WATANABE, R.; MATSUSHIMA, R.; OIKAWA, H.; NAGAI, S.; KAMIYAMA, T.; BABA, K; MIYAZONO, A.; KOSAKA, Y.; KAGA, S.; MATSUYAMA, Y. \& SUZUKI, T. Toxin Profiles of Okadaic Acid Analogues and Other Lipophilic Toxins in Dinophysis from Japanese Coastal Waters. Toxins, v. 10, n. 11, p. 457, 2018. https://doi.org/10.3390/toxins10110457

VISCIANO, P.; SCHIRONE, M.; BERTI, M.; MILANDRI, A.; TOFALO, R.; SUZZI, G. Marine biotoxins: occurrence, toxicity, regulatory limits and reference methods. Frontiers in microbiology, v.7, 1051, 2016. https://doi.org/10.3389/fmicb.2016.01051

WU, S.; DUAN, N.; ZHANG, H.; WANG, Z. Simultaneous detection of microcysin-LR and okadaic acid using a dual fluorescence resonance energy transfer aptasensor. Analytical and bioanalytical chemistry, v.407, n. 5, p.1303-1312, 2015. https://doi.org/10.1007/s00216-014-8378-3

YASUMOTO, T.; OSHIMA, Y.; YAMAGUCHI, M. Occurrence of a new type of shellfish poisoning in the Tohoku district. Bulletin of the Japanese Society of Scientific Fisheries, v.44, n.11, p. 1249-1255, 1978. https://doi.org/10.2331/suisan.44.1249 